\section{DEATH FROM THE BURSTING OF A TONSILLAR ABSCESS.}

By Alexander Lyons, L.R.C.P. \& S. Edin.

THE following may be of interest. A man, aged 28 years, was admitted by me into the Torbay Hospital at 9.30 A.M. on August 13th suffering from a very large suppurative tonsillitis on the left side. He was given a warm bath and put to bed where he partook of a glass of milk. About half an hour afterwards the nurse in charge of the ward heard him coughing feebly and on going to ascertain the cause was surprised to find him cyanosed. She sent for me and I went immediately but the patient was dead when I arrived. I do not think that more than five or six minutes could have elapsed between the time when the nurse heard him cough and my arrival at the patient's bed-side.

At the post-mortem examination I found that the abscess had burst and that a large amount of pus had got into the upper part of the larynx.

On looking up the literature on the subject I find only one case of a similar kind recorded-viz., by Hilton Fagge. Torquay.

\section{A CASE OF FOREIGN BODY IN THE NASO-PHARYNX.}

BY RICHARD LAKE, F.R.C.S. ENG.,

SURGEON TO THE METROPOLITAN EAR, NOSE, AND THROAT HOSPITAL, ETC.

THE presence of foreign bodies in the naso-pharynx appears to me, as far as $I$ am able to ascertain, of sufficient rarity to justify the brief report of a case, although it is true that the symptoms did not amount to more than discomfort or inconvenience and that also in this instance the presence of the foreign body was not suspected.

The patient, a married woman, aged 48 years, was sent to me in July, 1900, by Mr. H. Beadnell Gill, who desired my opinion as to the question of involvement of any of the accessory nasal sinuses. The history was peculiar. For some years the patient had blown from the nose every morning either matter (probably muco-pus) or matter with hard offensive crusts. At times these were, according to her description, covered with mildew. The total duration of this trouble was about 14 years. On examining the patient there was obviously rhinitis sicca et atrophica and the naso-pharyngeal vault could be distinctly seen covered apparently with a crust of congealed mucus, blackish in colour. The naso-pharynx was so irritable that it was impossible to get any view from behind.

I did not see the patient again until March 3rd of this year, but when she came to see me, stating that she had a sensation of burning in the tongue, it was still impossible to get a look at the naso-pharynx. I then ordered the use of peroxide of hydrogen (10 volumes) to the vault of the nasopharynx by means of a post-nasal syringe. Three days later a large fragment of the wing of the seed vessel of the ash or sycamore was removed from the naso-pharynx by the patient. The accompanying figure represents the piece removed.

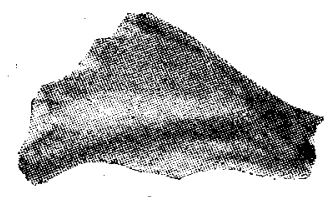

$$
\text { Xis his }
$$

Foreign body removed from naso-pharynx (natural size).

It is impossible to say when this foreign body was introduced into the nose and it is also equally impossible more than to speculate as to whether the inflammatory condition of the naso-pharynx was a result of its presence or whether the patient had suffered from some such condition before which had allowed of the foreign matter being more easily retained.

It is hardly necessary to state that the patient's condition has been much improved now that it is possible for remedial agents to be directly applied to the vault of the phargnx.

Harley-st reet, W.

\section{g d dittror}

OF

\section{HOSPITAL PRACTICE,}

\section{BRITISH·AND FOREIGN.}

Nulla autem est alia pro certo noscendi via, nisi quamplurimas et morborum et dissectionum historias, tum aliorum tum proprias collectas habere, et inter se comparare.-MoRGAGNI De Sed. et Caus. Morb., lib. iv., Procemium.

\section{SIDCUP COTTAGE HOSPITAL.}

A CASE OF SUPPURATIVE THROMBOSIS OF THE LATERAL SINUS ; OPERATION ; RECOVERY.

(Under the care of Dr. T. M. CALLENDER, )

THE treatment of the jugular vein in cases of middle-ear disease is dealt with very fully in a paper by $\mathrm{Mr}$. C. A. Ballance which appears in this number of THE LANCET, at p. 795. Ligature of the jugular vein for sinus thrombosis appears to have been first suggested by Sir Victor Horsley. ${ }^{1}$

The patient was a man, aged 38 years. His previous health had been good. His wife had recently died from phthisis. He had three healthy children. He suffered from a "touch of the sun" six weeks before admission to hospital. On August 19th, 1901, he complained of a foul discharge from the right ear. He also complained of general weakness but there was no pain in the head or tenderness over the mastoid. The temperature on admission to hospital was $1008^{\circ} \mathrm{F}$.; next morning it had fallen to $98.2^{\circ}$. At noon of the following day he had a violent rigor and the temperature ran up to $105.8^{\circ}$ and the pulse to 142 . The patient became unconscious. After consultation with Dr. G. W. Davis and Mr. H. A. Duffett of Sidcup Dr. Callender decided at once to explore the mastoid and while getting ready to operate the patient was sponged with tepid water, with the result that the temperature was reduced to $102 \cdot 2^{\circ}$ and by the time he was on the operating-table he was conscious and consented to operation. A.C.E. was administered. Dr. Callender cut down on the mastoid, gouged away the bone, and found a quantity of foul pus in the cells ; free communication was made between the wound and the auditory canal. The wound was douched and a gauze drain was put in. The patient seemed better for 24 hours after operation, but on the following evening his temperature was $104^{\circ}$. The discharge from the wound and ear was free and with cold sponging the temperature fell to normal. Next morning (two days after the operation on the mastoid) the patient had another very severe rigor and the temperature ran up to $104^{\circ}$. He complained of stiffness of the neck, but there was no pain or tenderness over the internal jugular and no sickness. His breath was foul. Dr. Callender resolved to operate again and to explore the lateral sinus as it was evident that the entire source of the mischief had not been reached, the rigors and foul breath which were assumed as being due to pyæmic pulmonary complications (though no definite physical signs could be made out in the lungs at this time) making the diagnosis of suppurative thrombosis of the lateral sinus probable. A.C.E. was again administered. Bone was gouged away over the lateral sinus. A hypodermic needle was thrust into the sinus and a little sero-pus was obtained, but no blood. The internal jugular vein was then cut down upon and ligatured, cutting between a double ligature, The sinus was opened freely ; an opening was made in the upper end of the jugular into which was inserted the point of a No. 8 gum elastic catheter; a ligature was put round the vein and catheter to prevent escape of the contents of the vein into the wound. The lateral sinus was gently syringed from below upwards through a catheter with 1 in 4000 solution of perchloride of mercury. A large quantity of very foul pus and clotted blood came from the lateral sinus. The internal jugular vein was then ligatured above the opening made for the catheter, cut short, and the wound in the neck was closed. The lateral sinus was packed with iodoform gauze. The wound was dressed each day, douched out with 1 in 4000 perchloride, and packed with gauze. The

1 Jacobson and Steward: Operations of Surgery, fourth edition, vol. i., p. 256 
patient improved wonderfully after the second operation, but several complications delayed convalescence. He developed a large pyæmic abscess in the back and a fœtid bronchitis. He had also an abscess in the base of the right lung which he was able to empty per mouth each morning, the expectoration being very offensive. A few tubercle bacilli were found in the sputum. Dr. Callender endeavoured to strike the abscess in the lung with an aspirating needle, without success, however, as regards reaching the abscess, but a pneumothorax developed and this, Dr. Callender presumed, by making the lung contract helped to obliterate the abscess cavity and also gave the lung rest. The patient expressed himself as feeling much better after the pneumothorax appeared, the amount of expectoration became much less and not so fœitid. An abscess formed in the wound in the neck which healed after being freely opened. Seven weeks after the operation on the lateral sinus the patient got a letter for admission to St. Mary's Hospital, London, where he was kept for a short time, and after being at a convalescent home at Ramsgate for a month he returned home in good health and able to resume his work. The facial nerve was unfortunately damaged and has not recovered its function though improvement is apparent.

Remarks by Dr. CALLENDER. - There are several points of interest in the case. 1. The few subjective symptoms; the patient never complained of pain in the head or neck. There was stiffness of the neck but no pain or tenderness. 2. Persistence of rigors and high temperature after the mastoid had been freely opened made the diagnosis of lateral sinus mischief probable. 3. The foul breath and expectoratimn pointed to pyæmic pulmonary complications, tbough at first, there being absence of physical signs in the lungs, it was thought that the foulness of the breath might be due to pus from the Eustachian tubes. 4. The improvement of the pulmonary abscess after pneumothorax had been produced was interesting.

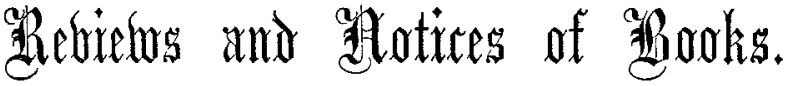

The Diseases of Children. By JAMES FREDERICK GoodHART, M.D. Aberd., with the assistance of GEORGE Frederick STILL, $y^{r} \mathrm{D}$. Cantab. Seventh edition. London: J. \& A. Churchill. 1902. $\mathrm{P}_{\rho}$. 813. Price 12s. $6 d$.

THE preparation of the seventh edition of Goodhart's "Diseases of Children" has evidently entailed a very considerable amount of revision; certain sections have, indeed, been almost completely rewritten. Among the subjects which are now added for the first time or which are so com. pletely remodelled as almost to defy recognition those which deal with the feeding of infants, with the diseases of the nervous system, with hypertrophic pyloric stenosis, and with achondroplasia are perhaps the most important. The chapter on rheumatism has also in several notable respects been subjected to the process of revision with the result that it constitutes one of the most interesting and enlightened chapters in the book. However, we do not feel altogether convinced that a "student" will gain such a clear clinical picture of what Dr. Goodhart calls the "composite" of the disease as he would do had he to rely for his instruction on any one of the former editions. To draw a clear line of demarcation between the "status rheumaticus" and acute rheumatism has strained the intellectual resources of other authors besides Dr. Goodhart and Dr. Still, and it is instructive to follow the ingenious generalisations and circumlocutory processes whereby all direct solutions of the problem a're shelved or evaded. "Children," we are told, " do indeed suffer from typical acute rheumatism, with its fever, its pain, its swellings of the joints, its sweating, but to circumscribe it (i.e., the term rheumatism) by these limits would be to ignore the larger part of the field of its workings." For the purpo-es of establishing a diagnosis it is suggested that we should rely on the family history and a record of small and insignificant ailments. Growing pains, skin lesions, nervous irritability, and anæmia-in fact, the same group of symptoms which certain authorities, and notably French writers, refer to the arthritic diathesis-are the hereditary conditions which, according to the authors, constitute the "status rheumaticus," and they are to be ascribed to certain inherent faults of the nervous system and to certain disabilities of nutrition. The authors admit, indeed, that the pathology of rheumatism is still a much vexed question and proceed to explain that "of late evidence has been collecting which would seem to show that it may possibly be of microbic origin." We may be quite wrong in the assumption, but after carefully reading this chapter on rheumatism we cannot help thinking that Dr. Goodhart and Dr. Still are not in absolute agreement on its essential pathology and that there have been mutual antagonisms as there have been mutual concessions. At all events, there are indications of a distinct disinclination on the part of the writers, metaphorically speaking, to burn one set of boats behind them and to abandon the neurotrophic diathesis before adequate transport of a bacteriological character has been provided; there is, in fact, a tendency to halt between two opinions.

In the chapter on tuberculosis the authors incline to the belief that infection in infancy is chiefly by way of the respiratory tract; without denying that the germs of tuberculosis do occur in milk they do not regard milk as a frequent medium of infection. However, it must be remembered that the lungs can become infected through other channels than through the air-passages, and whether lungs or bowel become demonstrably infected may be merely a question of local resistance. The alimentary tract must indeed be endowed with considerable power of resistance or from the swallowing of sputum it would almost invariably become infected in all cases of pulmonary tuberculosis. We do not think that, as far as tuberculosis is concerned, the authors have established their case against milk infection, or, indeed, against infection generally by way of the gastrointestinal tract.

The chapter on the feeding of infants, especially with reference to that part of it which concerns the preparation of milk mixtures, is, in our opinion, altogether inadequate ; and, in view of the importance of the subject, it is disproportionately short. Moreover, nearly a page of valuable space is taken up by a table which is quite useless as it stands, without instructions as to how to employ it. This table, which appears on page 47, gives in detail the percentage composition of milk suitable for the various ages of infancy and it might just as well have been omitted.

We are glad to notice that the vigorous and refreshing style which rendered former editions of the work such pleasant reading still retains its directness of expression. Although in his preface Dr. Goodhart says " he gladly 'remits' to Dr. Still the chief responsibility for the additions and improvements," it is clear that the latter has found some difficulty in overcoming the literary troubles of dual authorship. For instance, there is no consistency in the use of the first person singular or of the first person plural and it is difficult in places to understand whether "I" means I, Dr. Goodhart, or I, Dr. Still, just as there is ambiguity about the meaning of the "we's." We do not know which author is responsible for them but we cannot help drawing attention to the following sentences and asking for a literal and literary interpretation: "The life of the child is balancing" (p. 433) and "I think that rheumatism taints more than an average of such." Again, we would ask how a new-born infant can sit up (p. 21) or how it is that the " healthiest children" are liable to show symptoms of infantile paralysis (p. 527). Might not also the frequent references to the late Dr. Sturges indicate in some way or other that this lamented physician is no longer with us? To be still further critical we would call 